\title{
Media Pembelajaran Visual Menggunakan Canva pada Materi Sistem Gerak
}

\author{
Tenty Analicia ${ }^{*}$, Relsas Yogica ${ }^{2}$ \\ 1,2 Jurusan Biologi, FMIPA, Universitas Negeri Padang, Padang, Indonesia
}

\section{ART I C L E I N F O}

Article history:

Received August 26, 2021

Revised August 28, 2021

Accepted September 30, 2021

Available online December 25, 2021

Kata Kunci:

Media Visual, Canva, Biologi

Keywords:

visual media, canva, biology

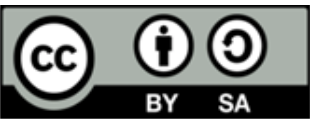

This is an open access article under the CC BY-SA license.

Copyright $(2021$ by Author. Published by Universitas Pendidikan Ganesha.

\begin{abstract}
A B S T R A K
Materi sistem gerak pada manusia dikatakan menarik bagi peserta didik, namun materi ini sulit dipahami. Peserta didik belum sepenuhnya mengaplikasikan manfaat mempelajari materi sistem gerak pada manusia. Hal ini berpengaruh pada hasil belajar siswa yang rendah. Penelitian ini bertujuan untuk menghasilkan media pembelajaran visual menggunakan materi Canva on Motion System. Media pembelajaran visual divalidasi oleh 2 dua orang ahli dan 1 orang guru untuk menguji kepraktisan. Metode yang digunakan untuk mengumpulkan data yaitu observasi, wawancara, dan kuesioner. Instrumen yang digunakan untuk mengumpulkan data yaitu kuesioner. Teknik yang digunakan dalam analisis data yaitu analisis deskriptif kualitatif dan kuantitatif. Hasilnya, media pembelajaran visual menggunakan Canva telah dikembangkan menggunakan 3 tahap model IDI yaitu tahap define yang bertujuan untuk mendapatkan gambaran kondisi di lapangan dengan menyebarkan angket respon siswa dan wawancara kepada guru, tahap develop dengan merancang media pembelajaran visual menggunakan canva dan divalidasi oleh ahli (validator), dan tahap evaluasi bertujuan untuk mengetahui sejauh mana manfaat, kemudahan, dan efisiensi waktu penggunaan media oleh guru dan siswa. Nilai validitas sebesar $89,68 \%$ dengan kriteria valid, kepraktisan oleh guru sebesar $91,87 \%$ dengan kriteria sangat valid dan siswa dengan kriteria sangat valid $90,06 \%$. Hasil penelitian menunjukkan bahwa media pembelajaran video menggunakan Canva valid dan praktis untuk pembelajaran.
\end{abstract}

\section{A B S T R A C T}

The motion system material in humans is interesting for students, but this material is difficult to reach. Learners have not fully implemented the benefits of learning the motion system material in humans. It affects the low student learning outcomes. This study aims to produce visual learning media using Canva on Motion System materials. 2 experts and 1 teacher validated visual learning media to test its practicality. The methods used to collect data are observation, interviews, and questionnaires. The instrument used to collect data is a questionnaire. The technique used in data analysis is descriptive qualitative and quantitative analysis. As a result, visual learning media using Canva has been developed using 3 stages of the IDI model, namely the define stage, which aims to get an overview of conditions in the field by distributing student response questionnaires and teacher interviews, the development stage by designing visual learning media using Canva and validated by experts (validators). The evaluation phase aims to determine the extent of the benefits, convenience, and time efficiency of using media by teachers and students. The validity value is $89.68 \%$ with valid criteria, practicality by teachers is $91.87 \%$ with very valid criteria, and students with very valid criteria $90.06 \%$. The results of the study show that the video learning media using Canva is valid and practical for learning.

\section{PENDAHULUAN}

Belajar merupakan proses bagi peserta didik dalam membangun gagasan atau pemahaman sendiri (Ngabekti et al., 2019; Prasedari et al., 2019). Kegiatan proses pembelajaran hendaknya memberikan kesempatan kepada peserta didik untuk melakukan hal itu secara lancar dan termotivasi (Goudeau et al., 2021; Hockings et al., 2018). Suasana belajar yang diciptakan guru harus melibatkan peserta didik secara aktif, misalnya mengamati, bertanya dan mempertanyakan, menjelaskan, dan sebagainya (Azmi, 2015; 
Suprihatin, 2015). Proses pembelajaran aktif untuk memperoleh informasi, keterampilan, dan sikap akan terjadi melalui suatu proses pencarian dari diri peserta didik (Dewi et al., 2019; Pravitasari \& Yulianto, 2018; Susiloningsih, 2016). Dalam pembelajaran setidaknya ada 2 komponen penting yang harus diperhatikan, yaitu metode dan media pembelajaran. Metode pembelajaran merupakan sebuah cara yang digunakan guru dalam mempersiapkan kegiatan belajar sehingga tujuan pembelajaran dapat dicapai secara maksimal (Dewi et al., 2019; Febiharsa \& Djuniadi, 2018; Harahap et al., 2021). Proses komunikasi dalam kegiatan pembelajaran dapat dibantu dengan menggunakan media pembelajaran.

Media pembelajaran adalah sarana yang dapat digunakan oleh guru sebagai sarana yang memudahkan belajar siswa (Nababan, 2020; Saripudin et al., 2018; Suhandra, 2018). Berdasarkan hasil wawancara dengan salah seorang guru Biologi di SMA Pertiwi 2 Padang diperoleh informasi terkait motivasi peserta didik untuk memahami materi dan penggunaan media dalam pembelajaran Biologi. Dalam memahami materi peserta didik memiliki motivasi yang rendah. Hal ini ditunjukkan dengan seringnya peserta didik mengantuk dan tidak fokus saat belajar. Selanjutnya, media yang digunakan dalam pembelajaran Biologi di SMA Pertiwi 2 Padang adalah Microsoft Power Point, charta, torso, lingkungan, buku-buku pendukung seperti ensiklopedia, video-video Youtube, dan Lembar Kerja Peserta Didik (LKPD). Berdasarkan observasi terhadap peserta didik kelas XI MIPA di SMA Pertiwi 2 Padang diperoleh informasi terkait cara belajar peserta didik. Hasil analisis lembar observasi menyatakan $56,56 \%$ cara belajar peserta didik secara visual, 26,08\% cara belajar peserta didik secara audiovisual, dan 17,39\% cara belajar peserta didik yang melibatkan gerakan atau kinestetik. Berdasarkan hasil angket yang peneliti berikan kepada 24 peserta didik Kelas XI di SMA Pertiwi 2 Padang, menunjukkan bahwa materi sistem gerak pada manusia dikatakan menarik bagi peserta didik, namun materi ini sulit dipahami. Peserta didik belum sepenuhnya mengaplikasikan manfaat mempelajari materi sistem gerak pada manusia. Pada dasarnya, materi sistem gerak pada manusia juga membahas mengenai proses pembentukan tulang sejak lahir hingga dewasa dan menjaga tulang agar tetap sehat. Berdasarkan hasil angket analisis yag diisi oleh guru diperoleh bahwa media pembelajaran visual menggunakan Canva sangat bagus untuk materi sistem gerak pada manusia. Hal ini disebabkan karena kondisi pandemi Covid-19, pembelajaran dialihkan menjadi pembelajaran dalam jaringan (daring) (Andel et al., 2020; Anitha Kumari et al., 2020; Cha \& So, 2021; Noer et al., 2021).

Berdasarkan permasalahan tersebut, maka dibutuhkan komponen-komponen pembelajaran, yaitu media pembelajaran visual, yang dapat memfasilitasi dalam pembelajaran daring (Ellianawati et al., 2021; Jogezai et al., 2021; Kristanto et al., 2021). Penggunakan media pembelajaran visual menggunakan program desain Canva. Selain itu, dengan media pembelajaran visual menggunakan Canva proses pembelajaran dapat terlaksanakan dengan nyaman. Media pembelajaran berbasis digital dapat meningkatkan semangat belajar bagi peserta didik serta pembelajaran dapat diulang kembali karena media dapat digunakan secara online maupun offline (Ambarita, 2021; Kusnandar, 2014; Setiawan et al., 2020). Media pembelajaran yang dikembangkan yaitu media pembelajaran visual menggunakan Canva. Beberapa keunggulan yang dimiliki program desain Canva ini adalah: (1) memiliki beragam desain grafis, animasi, template, dan nomor halaman yang menarik, (2) dapat mendesain media pembelajaran kapanpun dan di manapun tanpa harus menggunakan laptop, tetapi juga dapat menggunakan handphone, dan (3) pada media Canva hasil yang telah kita buat dapat diunduh dengan beragam format baik dalam bentuk pdf maupun jpg (Rahmasari \& Yogananti, 2021; Yundayani et al., 2019). Untuk menerapkan presentasi, dapat dilakukan secara offline dan dikolaborasikan dengan media lainnya. Jadi, media pembelajaran visual menggunakan Canva ini dibuat dengan menggunakan aplikasi Canva dan dibantu dengan Microsoft Power Point untuk menambahkan gerakan pada animasi.

Temuan penelitian sebelumnya juga membuktikan bahwa penggunaan media pembelajaran berbasis Canva layak digunakan dalam kegiatan pembelajaran (Elvira \& Delsiana, 2019; Resmini et al., 2021). Temuan penelitian lainnya juga menyatakan bahwa media pembelajaran visual menggunakan Canva dapat meningkatkan motivasi belajar peserta didik (Junaedi, 2021; Pelangi, 2020). Penggunaannya media ini sangat efektif, baik digunakan secara luring maupun daring. Pengembangan media pembelajaran visual ini ini juga didasarkan pada kenyataan di lapangan. Belum ada pengembangan media pembelajaran visual menggunakan Canva yang digunakan di SMA Pertiwi 2 Padang, sehingga perlu dikembangkan media pembelajaran visual menggunakan Canva yang valid dan praktis. Tujuan penelitian ini yaitu mengembangkan media pembelajaran visual menggunakan Canva yang digunakan di SMA Pertiwi 2 Padang. Diharapkan media pembelajaran ini dapat digunakan dalam pembelajaran.

\section{METODE}

Jenis penelitian ini yaitu pengembangan dengan menggunakan model Instructional Development Institute (IDI). Model ini terdiri dari tiga tahapan, yaitu pendefinisian (define), pengembangan (develop), dan penilaian (evaluate). Pada tahap ini dilakukan analisis awal akhir (need assessment), analisis awal akhir dikenal juga dengan tahap analisis kebutuhan (needs assessment), yang bertujuan untuk 
mendapatkan gambaran kondisi di lapangan. Pada analisis kebutuhan dilakukan penyebaran angket respon peserta didik terhadap media pembelajaran serta wawancara dengan guru di SMA Pertiwi 2 Padang. Tujuan penyebaran angket ini untuk mengetahui permasalahan peserta didik dalam menggunakan media pembelajaran. Pada tahap pengembangan ini disusun draft (rancangan) awal media pembelajaran visual penggunaan program desain Canva. Hasil analisis awal akhir menjadi landasan untuk merancang media penggunaan program desain Canva. Media yang dirancang kemudian dikonsultasikan dengan ahli atau pakar media sebagai validator media.

Metode yang digunakan untuk mengumpulkan data yaitu observasi, wawancara, dan kuesioner. Intrumen yang digunakan pada penelitian ini yaitu kuesioner. Pada tahap ini dilakukan validasi terhadap media yang dibuat. Teknik yang digunakan dalam analisis data yaitu analisis deskriptif kualitatif dan kuantitatif. Validasi dilakukan oleh pakar (validator) yang terdiri dari dua orang ahli mediadan satu orang guru pengampu mata pelajaran Biologi. Validasi ini menggunakan instrument penelitian (angket). Masukan dari validator digunakan untuk memperbaiki media yang sedang dikembangkan. Media ini akan direvisi jika dinyatakan tidak valid oleh validator. Peneliti dalam hal ini mengadakan uji coba terhadap produk yang telah dikembangkan atau dihasilkan. Tujuan dari uji coba adalah mengumpulkan data tentang kepraktisan, setelah uji validitas media penggunaan program desain Canva yang telah direvisi, diuji cobakan disekolah. Uji praktikalitas adalah tingkat kepraktisan produk penelitian yang digunakan oleh guru dan peserta didik.

\section{HASIL DAN PEMBAHASAN}

\section{Hasil}

Data ketersediaan dan penggunaan media pembelajaran yang diperoleh di SMA Pertiwi 2 Padang adalah sebgai berikut. Media pembelajaran biologi yang tersedia adalah Microsoft Power Point, alat-alat laboratorium, torso, lingkungan, buku-buku pendukung seperti ensiklopedia, video-video dari Youtube, papan tulis, dan Lembar Kerja Peserta Didik (LKPD), tetapi tidak semua media pembelajaran yang tersedia praktis dan efektif digunakan bagi guru dan peserta didik. Kenyataannya, guru lebih dominan menggunakan media pembelajaran menggunakan Microsoft Power Point, dan LKPD, sehingga terkesan monoton bagi peserta didik dan berdampak terhadap minat dan motivasi dalam belajar. Analisis peserta didik dilakukan untuk mengidentifikasi kebutuhan media pembelajaran sesuai dengan cara belajar peserta didik. Analisis ini dilakukan melalui penyebaran lembar observasi cara belajar peserta didik. Berdasarkan hasil observasi, cara belajar peserta didik terhadap 24 orang peserta didik kelas XI MIA di SMA Pertiwi 2 Padang didapatkan data bahwa peserta didik tersebut memiliki cara belajar dominan visual dengan persentase 56,56\%.

Analisis kurikulum dilakukan untuk mengidentifikasi kelemahan pembelajaran pada kompetensi dasar dan indikator pencapaian kompetensi pembelajaran tertentu ditinjau dari aspek media pembelajaran. Analisis ini dilakukan dari hasil wawancara guru dan lembar observasi peserta didik. Berdasarkan hasil wawancara guru dan hasil analisis lembar observasi peserta didik, materi pembelajaran biologi yang sulit dipahami pada materi kelas XI adalah Sistem Gerak dengan persentase sebesar 69,56\%. Pernyataan tersebut didukung oleh sebagian besar alasan peserta didik yang kesulitan memahami materi sistem gerak karena menyangkut proses dan sistem serta banyak organ-organ yang terlibat. Tahap pengembangan, kegiatan yang dilakukan yaitu merancang media pembelajaran menggunakan desain Canva pada materi sistem gerak, Mendesain tampilan media, mengumpulkan materi, mengumpulkan materi, menyusun storyboard media, membuat media pembelajaran visual pada materi sistem gerak. Tahap selanjutnya yaitu uji validitas media. Uji validitas media pembelajaran visual menggunakan Canva pada materi Sistem Gerak dilakukan oleh validator yang terdiri dari dua orang ahli melalui angket validasi. Pada tahap validasi terdapat saran-saran dari para validator yang menjadi dasar pertimbangan untuk melakukan revisi media pembelajaran visual menggunakan Canva pada materi Sistem Gerak. Hasil analisis angket validasi media pembelajaran visual menggunakan Canva pada Tabel 1.

Tabel 1. Validitas Media Pembelajaran Visual Menggunakan Canva pada Materi Sistem Gerak

\begin{tabular}{lcccccc}
\hline $\begin{array}{c}\text { Aspek } \\
\text { Penilaian }\end{array}$ & \multicolumn{2}{c}{$\begin{array}{c}\text { Penilaian } \\
\text { Validator }\end{array}$} & & $\begin{array}{c}\text { Jumlah } \\
\text { Skor }\end{array}$ & $\begin{array}{c}\text { Nilai } \\
\text { Validitas }\end{array}$ & Kategori \\
\cline { 2 - 4 } & I & II & III & & & Sangat valid \\
Kelayakan Isi & 23 & 20 & 24 & 67 & $93,05 \%$ & Valid \\
Kebahasaan & 21 & 20 & 23 & 64 & $88,89 \%$ & Sangat valid \\
Penyajian & 47 & 37 & 47 & 131 & $90,97 \%$ & Valid \\
Kegrafikan & 32 & 32 & 39 & 103 & $85,83 \%$ & Valid \\
\hline
\end{tabular}


Berdasarkan Tabel 1 rata-rata validitas yaitu 89,68\% dengan kriteria valid. Ini memiliki kesimpulan bahwa media pembelajaran visual menggunakan Canva yang dikembangkan valid, sehingga bisa digunakan dalam proses pembelajaran. Tahap penilaian dilakukan dengan uji praktikalitas media pembelajaran visual menggunakan Canva pada materi Sistem Gerak terhadap guru dan peserta didik kelas XI di SMA Pertiwi 2 Padang melalui angket praktikalitas. Berdasarkan penilaian yang diberikan oleh guru mengenai media pembelajaran menggunakan canva rata-rata mendapatkan skor 91,87\%, sehingga dapat sangat praktis. Berdasarkan penilaian yang diberikan oleh siswa mengenai media pembelajaran menggunakan canva rata-rata mendapatkan skor 90,6\%, sehingga dapat sangat praktis.

\section{Pembahasan}

Hasil analisis data menunjukkan bahwa media pembelajaran visual menggunakan Canva pada materi Sistem Gerak yang dikembangkan dikategorikan valid. Hal ini sesuai dengan penelitian sebelumnya yang menyatakan bahwa dalam pembuatan media pembelajaran harus memerhatikan kesesuaian dengan kompetensi yang didasarkan pada kurikulum yang berlaku (Gever et al., 2021; Megawati \& Utami, 2020; Saripudin et al., 2018). Ditinjau dari aspek kelayakan isi, media pembelajaran visual menggunakan Canva pada Materi Sistem Gerak memiliki nilai validitas sangat tinggi dengan kategori sangat valid. Hal ini menunjukkan bahwa media pembelajaran visual menggunakan Canva pada Materi Sistem Gerak yang dikembangkan telah sesuai dengan Kurikulum 2013 berdasarkan tuntutan kompetensi dasar, indikator pencapaian kompetensi, dan tujuan pembelajaran. Kejelasan kompetensi dan indicator pencapaian akan memudahkan siswa dalam belajar (Anggraini et al., 2018; Fitriyana et al., 2020; Kamelia, 2019).

Hal ini menunjukkan bahwa media pembelajaran visual menggunakan Canva pada materi Sistem Gerak yang dikembangkan telah memiliki susunan kalimat yang tepat, jelas, dan sederhana sesuai dengan kaidah penulisan yang baik dan benar. Susunan kalimat yang ditulis dengan kaidah penulisan yang baik dan benar akan memudahkan siswa dalam memahami materi pembelajaran (Liu et al., 2021; Pratono et al., 2018; Subarkah et al., 2021). Ditinjau dari aspek penyajian, media pembelajaran visual menggunakan Canva pada materi Sistem Gerak memiliki dengan kategori sangat valid. Aspek penyajian media yang menarik dapat meningkatkan semangat belajar siswa (Irwansyah et al., 2017; Neppala et al., 2018). Hal ini menunjukkan bahwa media pembelajaran visual menggunakan Canva pada materi Sistem gerak telah sesuai dengan indikator dan tujuan pembelajaran. Selain itu, kelengkapan materi ajar telah sesuai dengan urutan indikator sehingga peserta didik dapat belajar secara sistematis dan terarah. Hal ini menunjukkan bahwa desain media pembelajaran visual menggunakan Canva pada materi Sistem Gerak yang dikembangkan sudah baik dan menarik meliputi bentuk dan ukuran huruf yang sesuai, gambar, video, dan animasi yang disajikan menarik dan relevan dengan materi, serta pemilihan warna yang sesuai dan menarik. Kemenarikan media dapat meningkatkan motivasi siswa (Ardianti et al., 2019; Aufa et al., 2021; Purnamasari et al., 2020).

Temuan penelitian sebelumnya juga menyatakan bahwa media pembelajaran menarik dapat memotivasi siswa dalam belajar (Astalini et al., 2019; Fonda \& Sumargiyani, 2018; Hamzah \& Mentari, 2017). Temuan penelitian sebelumnya menyatakan bahwa media pembelajaran visual dapat memudahkan siswa dalam belajar (Agung et al., 2017; Ambarsari \& Hartono, 2017; Lisdayanti et al., 2014). Dapat disimpulkan bahwa media visual cocok diterapkan dalam pembelajaran. Ditinjau dari aspek kemudahan penggunaan, media pembelajaran visual menggunakan Canva pada materi Sistem Gerak dinilai sangat praktis, sehingga dapat digunakan dalam pembelajaran.

\section{SIMPULAN}

Media pembelajaran visual menggunakan Canva pada materi Sistem Gerak mendapatkan kategori valid dan sangat praktis bagi guru dan siswa. Dapat disimpulkan bahwa media pembelajaran visual menggunakan Canva pada materi Sistem Gerak layak diterapkan dalam proses pembelajaran, sehingga dapat meningkatkan motivasi dan semangat belajar siswa.

\section{DAFTAR RUJUKAN}

Agung, A. A. G., Widiana, I. W., \& Indrasuari, N. K. S. (2017). Pengembangan Aktivitas Pembelajaran Mengasosiasi Berbasis Media Gambar Berseri dalam Meningkatkan Proses Kognitif Siswa. Jurnal Ilmiah Sekolah Dasar, 1(3), 138. https://doi.org/10.23887/jisd.v1i3.10323.

Ambarita, E. (2021). Belajar Dari Rumah (BDR) Menggunakan Padlet Alternatif E-Learning pada Masa Pandemi Covid-19 (Studi Kasus Di SMAN 56 Jakarta). JIRA: Jurnal Inovasi Dan Riset Akademik, 2(1), 30-36. https://doi.org/10.47387/jira.v2i1.70.

Ambarsari, D. W., \& Hartono, B. (2017). Pengembangan Media Pop Culture Up Rumah Adat Jawa untuk 
Pembelajaran Menyusun Teks Deskripsi pada Peserta Didik SMP Kelas VII. Semantik, 6(2), 1. https://doi.org/10.22460/semantik.v6i2.p1-10.

Andel, S. A., de Vreede, T., Spector, P. E., Padmanabhan, B., Singh, V. K., \& Vreede, G. J. de. (2020). Do Social Features Help in Video-Centric Online Learning Platforms? A Social Presence Perspective. Computers in Human Behavior, 113(April), 106505. https://doi.org/10.1016/j.chb.2020.106505.

Anggraini, D., Relmasira, S., \& Tyas Asri Hardini, A. (2018). Penerapan Model Pembelajaran Student Teams Achievement Division (STAD) Melalui Media Pembelajaran Ular Tangga untuk Meningkatkan Kemampuan Berpikir Kritis dan Hasil Belajar IPS pada Peserta Didik Kelas 2 SD. Pendekar : Jurnal Pendidikan Berkarakter, 1(1), 324. https://doi.org/10.31764/pendekar.v1i1.379.

Anitha Kumari, T., Hemalatha, C. H., Subhani Ali, M., \& Naresh, R. (2020). Survey on Impact and Learning's of the Online Courses on the Present Era. Procedia Computer Science, 172, 82-91. https://doi.org/10.1016/j.procs.2020.05.167.

Ardianti, S. D., Wanabuliandari, S., Saptono, S., \& Alimah, S. (2019). A Needs Assessment of Edutainment Module with Ethnoscience Approach Oriented to the Love of the Country. Jurnal Pendidikan IPA Indonesia, 8(2), 153-161. https://doi.org/10.15294/jpii.v8i2.13285.

Astalini, A., Darmaji, D., Kurniawan, W., Anwar, K., \& Kurniawan, D. A. (2019). Effectivenes of Using E-Module and E-Assessment. International Journal of Interactive Mobile Technologies (IJIM), 13(09), 21-39. https://doi.org/10.3991/ijim.v13i09.11016.

Aufa, M. N., Rusmansyah, R., Hasbie, M., Jaidie, A., \& Yunita, A. (2021). The Effect of Using E-Module Model Problem Based Learning (PBL) Based on Wetland Environment on Critical Thinking Skills and Environmental Care Attitudes. Jurnal Penelitian Pendidikan IPA, 7(3), 401-407. https://doi.org/10.29303/jppipa.v7i3.732.

Azmi, N. (2015). Model Pembelajaran Inside Outside Circle (IOC)) untuk Meningkatkan Hasil Belajar Siswa dalam Proses Pembelajaran. Al Ibtida: Jurnal Pendidikan Guru MI, 2(1), 1-19. https://doi.org/10.24235/al.ibtida.snj.v2i1.180.

Cha, H., \& So, H.-J. (2021). Online Learning in K-12 Schools Amid Covid-19 in South Korea: Challenges and Opportunities. In Radical Solutions for Education in a Crisis Context. Lecture Notes in Educational Technology. https://doi.org/10.1007/978-981-15-7869-4_20.

Dewi, I. G. A. A. S. S., Sudatha, I. G. W., \& Sukmana, A. I. W. I. Y. (2019). Pengembangan Multimedia Pembelajaran Interaktif Berorientasi Pendidikan Karakter Mata Pelajaran Bahasa Bali. Journal of Education Technology, 3(3), 190. https://doi.org/10.23887/jet.v3i3.21745.

Ellianawati, E., Subali, B., Khotimah, S. N., Cholila, M., \& Darmahastuti, H. (2021). Face to Face Mode vs. Online Mode: A Discrepancy in Analogy-Based Learning During COVID-19 Pandemic. Jurnal Pendidikan IPA Indonesia, 10(3), 368-377. https://doi.org/10.15294/jpii.v10i3.30037.

Elvira, \& Delsiana. (2019). Canva Sebagai Media Pembelajaran pada Mata Pelajaran Dasar Listrik dan Elektronika. Jurnal Vokasional Teknik Elektronika Dan Informatika, 7(2), 80-81. https://doi.org/10.24036/voteteknika.v7i2.104261.

Febiharsa, D., \& Djuniadi, D. (2018). Pengembangan Media Pembelajaran Interaktif 3 Dimensi untuk Pembelajaran Materi Pengenalan Lingkungan pada Anak Usia Dini di Indonesia. Journal of Studies in Early Childhood Education (J-SECE), 1(1). https://doi.org/10.31331/sece.v1i1.590.

Fitriyana, N., Ningsih, K., \& Panjaitan, R. G. P. (2020). Penerapan Model Pembelajaran Savi Berbantuan Media Flashcard untuk Meningkatkan Aktivitas dan Hasil Belajar. Edukasi: Jurnal Pendidikan. https://doi.org/10.31571/edukasi.v18i1.1667.

Fonda, A., \& Sumargiyani, S. (2018). The Developing Math Electronic Module with Scientific Approach Using Kvisoft Flipbook Maker Pro for Xi Grade of Senior High School Students. Infinity Journal, 7(2), 109122. https://doi.org/10.22460/infinity.v7i2.p109-122.

Gever, V. C., Tunca, E. A., Boluwatife, A. A., Nwogbo, V. C., \& Chinweobo-Onuoha, B. N. (2021). Visual Media and Learning: Effect of Interactive Television Instruction as an Intervention Strategy for Improving the Critical Thinking Skills and Disposition of Out-of-School Nomadic Children in Nigeria. Learning and Motivation, 76. https://doi.org/10.1016/j.lmot.2021.101767.

Goudeau, S., Sanrey, C., Stanczak, A., Manstead, A., \& Darnon, C. (2021). Why Lockdown and Distance Learning during the COVID-19 Pandemic are Likely to Increase the Social Class Achievement Gap. Nature Human Behaviour. https://doi.org/10.1038/s41562-021-01212-7.

Hamzah, I., \& Mentari, S. (2017). Development of Accounting E-Module to Support the Scientific Approach of Students Grade X Vocational High School. Journal of Accounting and Business Education, 1(1), 78. https://doi.org/10.26675/jabe.v1i1.9751.

Harahap, S. A., Dimyati, D., \& Purwanta, E. (2021). Problematika Pembelajaran Daring dan Luring Anak Usia Dini bagi Guru dan Orang tua di Masa Pandemi Covid 19. Jurnal Obsesi : Jurnal Pendidikan Anak Usia Dini, 5(2), 1825-1836. https://doi.org/10.31004/obsesi.v5i2.1013. 
Hockings, C., Thomas, L., Ottaway, J., \& Jones, R. (2018). Independent Learning-What We Do When You're Not There. Teaching in Higher Education, 23(2), 145-161. https://doi.org/10.1080/13562517.2017.1332031.

Irwansyah, F. S., Lubab, I., Farida, I., \& Ramdhani, M. A. (2017). Designing Interactive Electronic Module in Chemistry Lessons. Journal of Physics: Conference Series, 895(1). https://doi.org/10.1088/17426596/895/1/012009.

Jogezai, N. A., Baloch, F. A., Jaffar, M., Shah, T., Khilji, G. K., \& Bashir, S. (2021). Teachers' Attitudes Towards Social Media (SM) Use in Online Learning Amid The COVID-19 Pandemic: The Effects of SM Use by Teachers and Religious Scholars During Physical Distancing. Journal Heliyon, 7(4), 1-9. https://doi.org/10.1016/j.heliyon.2021.e06781.

Junaedi, S. (2021). Aplikasi Canva Sebagai Media Pembelajaran Daring untuk Meningkatkan Kemampuan Kreatifitas Mahasiswa pada Mata Kuliah English for Information Communication and Technology. Bangun Rekaprima, 7(2). https://doi.org/10.32497/bangunrekaprima.v7i2,\%200ktober.3000.

Kamelia, K. (2019). Using Video as Media of Teaching in English Language Classroom: Expressing Congratulation and Hopes. Utamax : Journal of Ultimate Research and Trends in Education, 1(1), 3438. https://doi.org/10.31849/utamax.v1i1.2742.

Kristanto, A., Sulistiowati, ., \& Pradana, H. D. (2021). Brain-Based Online Learning Design in The Disruptive Era for Students in University. Journal of Educational and Social Research, 11(6), 277. https://doi.org/10.36941/jesr-2021-0147.

Kusnandar, K. (2014). Pengembangan Bahan Belajar Digital Learning Object. Jurnal Teknodik, 17(1), 583595. https://doi.org/10.32550/teknodik.v0i0.69.

Lisdayanti, N. P., Ardana, I. K., \& Suryaabadi, I. B. G. (2014). Pengaruh Model Pembelajaran Kooperatif Talking Stick Berbantuan Media Gambar terhadap Hasil Belajar IPA Siswa Kelas V SD Gugus 4 Baturiti. Journal Mimbar PGSD Universitas Pendidikan Ganesha Jurusan PGSD, 2(1). https://doi.org/10.23887/jjpgsd.v2i1.1962.

Liu, X., Kong, J., Jiang, M., \& Li, S. (2021). Interactive Information Module for Person Re-Identification. Journal of Visual Communication and Image Representation, 75. https://doi.org/10.1016/j.jvcir.2021.103033.

Megawati, \& Utami. (2020). English Learning with Powtoon Animation Video. Journal of Education Technology, 4(2), 110. https://doi.org/10.23887/jet.v4i2.25096.

Nababan, N. (2020). Pengembangan Media Pembelajaran Berbasis Geogebra dengan Model Pengembangan Addie di Kelas XI SMAN 3 Medan (Development of Geogebra-Based Learning Media With Addie Development Models in Class Xi Sman 3 Medan ). Inspiratif : Jurnal Pendidikan Matematika, 6(1), 37-50. https://doi.org/10.24114/jpmi.v6i1.19657.

Neppala, P., Sherer, M. V., Larson, G., Bryant, A. K., Panjwani, N., Murphy, J. D., \& Gillespie, E. F. (2018). An Interactive Contouring Module Improves Engagement and Interest in Radiation Oncology Among Preclinical Medical Students: Results of a Randomized Trial. Practical Radiation Oncology, 8(4), e190-e198. https://doi.org/10.1016/j.prro.2018.01.001.

Ngabekti, Prasetyo, Hardianti, \& Teampanpong. (2019). The Development of STEM Mobile Learning Package Ekosistem. Jurnal Pendidikan IPA Indonesia, 8(1), 81-88. https://doi.org/10.15294/jpii.v8i1.16905.

Noer, R. Z., Wahid, S. M. Al, \& Febriyanti, R. (2021). Online Lectures : An ilplementation of Full E-Learning Action Research. Jurnal Prima Edukasia, 9(1), 65-74. https://doi.org/10.21831/jpe.v9i1.35030.

Pelangi, G. (2020). Pemanfaatan Aplikasi Canva sebagai Media Pembelajaran Bahasa dan Sastra Indonesia Jenjang SMA/MA. Jurnal Sasindo Unpam, 8(2). https://doi.org/10.32493/sasindo.v8i2.79-96.

Prasedari, L. P. E., Pudjawan, K., \& Suranata, K. (2019). Pengaruh Model Pembelajaran Problem Based Learning Berorientasi Tri Pramana terhadap Hasil Belajar Matematika Siswa Kelas IV. Jurnal Ilmiah Kependidikan, 1(3), 50-60. https://doi.org/10.23887/jpmu.v1i2.20771.

Pratono, A., Sumarti, S. S., \& Wijayati, N. (2018). Contribution of Assisted Inquiry Model of E-Module to Students Science Process Skill. Journal of Innovative Science Education, 7(1), 62-68. https://doi.org/10.15294/jise.v7i1.20633.

Pravitasari, S. G., \& Yulianto, M. L. (2018). Penggunaan Multimedia Interaktif dalam Pembelajaran Bahasa Inggris (Studi Kasus di SDN 3 Tarubasan Klaten). Profesi Pendidikan Dasar, 1(1), 37. https: //doi.org/10.23917/ppd.v1i1.3825.

Purnamasari, N., Siswanto, S., \& Malik, S. (2020). E-Module as an Emergency-Innovated lLarning Source during the Covid-19 Outbreak. Psychology, Evaluation, and Technology in Educational Research, 3(1), 1-8. https://doi.org/10.33292/petier.v3i1.53.

Rahmasari, E. A., \& Yogananti, A. F. (2021). Kajian Usability Aplikasi Canva (Studi Kasus Pengguna Mahasiswa Desain). Andharupa: Jurnal Desain Komunikasi Visual \& Multimedia, 7(1). 
https://doi.org/10.33633/andharupa.v7i01.4292.

Resmini, S., Satriani, I., \& Rafi, M. (2021). Pelatihan Penggunaan Aplikasi Canva sebagai Media Pembuatan Bahan Ajar dalam Pembelajaran Bahasa Inggris. Abdimas Siliwangi, 4(2). https://doi.org/10.22460/as.v4i2p\%25p.6859.

Saripudin, E., Sari, I. J., \& Mukhtar, M. (2018). Using Macro Flash Animation Media on Motion Material to Improve Learning Achievement for Learning Science in Junior High School. Jurnal Penelitian Dan Pembelajaran IPA, 4(1), 68-75. https://doi.org/10.30870/jppi.v4i1.3316.

Setiawan, N. C. E., Dasna, I. W., \& Muchson, M. (2020). Pengembangan Digital Flipbook untuk Menfasilitasi Kebutuhan Belajar Multiple Representation pada Materi Sel Volta. Hydrogen: Jurnal Kependidikan Kimia, 8(2), 107. https://doi.org/10.33394/hjkk.v8i2.3194.

Subarkah, C. Z., Alhak, A. A., Sari, S., Ruswandi, U., \& Rochman, C. (2021). Developing E-Module on the Topic of Integrated Addictive Substances with Islamic Values. JTK (Jurnal Tadris Kimiya), 6(1), 16-25. https://doi.org/10.15575/jtk.v6i1.9802.

Suhandra, I. R. (2018). Pemanfaatan Media Gambar Berseri untuk Memperkaya Kemampuan Menulis Naratif Bahasa Inggris Siswa Kelas IX MTS NW Nurul Wathon Pengembur Lombok Tengah. $\begin{array}{llll}\text { TRANSFORMASI: Jurnal Masyarakat, } & \text { 14(1). }\end{array}$ https://doi.org/10.20414/transformasi.v14i1.576.

Suprihatin, S. (2015). Upaya Guru dalam Meningkatkan Motivasi Belajar Siswa. Urnal Pendidikan Ekonomi UM Metro, 3(1), 72-82.

Susiloningsih, W. (2016). Model Pembelajaran CTL (Contextual Teaching and Learning) dalam Meningkatkan Hasil Belajar Mahasiswa PGSD pada MataKuliah Konsep IPS Dasar. PEDAGOGIA: Jurnal Pendidikan, 5(1), 57. https://doi.org/10.21070/pedagogia.v5i1.89.

Yundayani, A., Susilawati, \& Chairunnisa. (2019). Investigating The Effect of Canva on Students' Writing $\begin{array}{lllll}\text { Skills. English Review: Journal of English Education, } & \text { (2). }\end{array}$ https://doi.org/10.25134/erjee.v7i2.1800. 